\title{
Implementation of Zakat Village Index (Survey in Binangun Village, Pataruman Sub District, Banjar City)
}

\section{Fitriyani Nurul Hakim, A. Jajang W. Mahri, and Aas Nurasyiah}

Economics and Islamic Finance Department, Universitas Pendidikan Indonesia Jl. Dr. Setiabudhi No. 229 Kota Bandung

\section{Abstract}

This research is based on the problem of less precisely the target and empowerment programs conducted by zakat management institutions both LAZ and BAZ. This study aims to build a conceptual model to describe and measure the condition of a village in order to be eligible to be empowered as a zakat village using the Zakat Village Index (IDZ). This study uses primary data and secondary data from village side and by interview through village apparatus and direct observation to the field by visiting RT and $\mathrm{RW}$ so the research is a descriptive quantitative research. There are five variables

Corresponding Author: Fitriyani Nurul Hakim fitriyaninurulhakim@student .upi.edu

Received: 10 February 2019 Accepted: 14 March 2019 Published: 28 March 2019

Publishing services provided by Knowledge E

(c) Fitriyani Nurul Hakim et al. This article is distributed under the terms of the Creative Commons Attribution License, which permits unrestricted use and redistribution provided that the original author and source are credited.

Selection and Peer-review under the responsibility of the ICIEBP Conference Committee.

\section{S OPEN ACCESS} measured in this study, they are economic, health, education, social humanitarian and da'wah variables. The research was conducted in Binangun Village, Pataruman Sub District, Banjar City. The calculation result of Zakat Village Index (IDZ) indicates that Binangun Village is included in good condition and can be considered to be empowered using zakat fund. Variables that have the lowest IDZ value are economic and health variables. For the zakat institution that will empower the Binangun Village, can be more focused on the two variables. Then for zakat management institution should use Zakat Village Index instrument (IDZ) to determine the target of the program and to know the requirement of society exactly so that program of channeling of zakat fund can be done effectively and efficiently.

Keywords: Community welfare, empowerment, Zakat Village Index

\section{Introduction}

Poverty is a benchmark for the success of a government in implementing development in a country (Nurzaman, 2011). Therefore, poverty is a benchmark for the success of a government in carrying out development programs in a country, even though the country has a high level of economic growth, it does not mean if the level of poverty in the country is still high. The Indonesian government in every regimes always makes poverty to be the main problem that must be resolved. Various policies to alleviate poverty proved that the government has been very consistent in alleviating poverty in Indonesia. 
Referring to Badan Pusat Statistik (BPS), the number of poverty figures in Indonesia is still relatively high and fluctuating but tends to decrease every year. In 2017 the number of poor people in Indonesia reached 27.77 million and Java became the largest contributor with a total of 14.79 million people (Rachman, 2017). Even from 34 provinces in Indonesia, three provinces on Java Island entered the order of the three largest number of poor people in Indonesia. The province of West Java itself ranks third after the provinces of East Java and Central Java with nalmost 3.8 million people.

Based on the amount of income per capita of the community, Banjar City occupies the lowest position with an average income of 289 thousand rupiah per month. Followed by Cirebon, which in this city most people work as farmers and fishermen. Then in the third position there is the city of Tasikmalaya, one of the causes of the low income of the people in this city is because many drivers of the economic sector are run by the Chinese community so that the economy of the indigenous people of Tasik is less developed. Then in the fourth and fifth positions there are the City of Bandung and the City of Cimahi, the two cities which are both close to the center of the West Java government have low per capita income because of the large number of residents who come from villages outside the city who actually work there, so that the people's income in theese both cities only reaches 400 thousand rupiah per month (dijawabarat.com, 2018).

Uniquely, based on the ranks of the Human Development Index (HDI) in West Java, Banjar City and Tasikmalaya City were included in the two cities with the lowest HDI in West Java. in 2016 Banjar had a HDI score of 70.09 .

According to BPS in the past four years, Banjar City's economic growth rate is less stable and fluctuating. One of the villages which affected by the weakening rate of economic growth in Banjar City is the Binangun Village Pataruman District, Banjar City. Based on the data above, we can see that the level of development in Banjar and the government programs have proven that they cannot solve the various kinds of living problems in the city of Banjar. It is evidenced by the low average income of the community, the unstable economic growth rate and the low human development index. Therefore, the programs that is needed to solve these problems is not only to reduce economic-based problems but can also improve the lives of people.

Islam as rahmatan lil alamin certainly has a solution to overcome the problem, one of them is a community-based zakat program. This zakat program is expected to be able to support all forms of development programs carried out by the government to alleviate poverty and improve the living standards of the people (Hartoyo, 2010). In addition, 
zakat funds are one of the instruments which is intended for the poor as stated in Q.S At-Taubah verse 60, Allah SWT says:

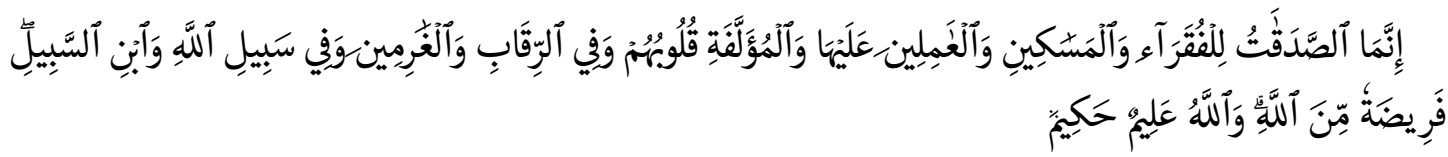

"The alms are only for the poor and the needy, and those who collect them, and those whose hearts are to be reconciled, and to free the captives and the debtors, and for the cause of Allah, and (for) the wayfarer; a duty imposed by Allah. Allah is Knower, Wise." (Q.S At-Taubah 60)

According to Mayor of Banjar Mayor Ade Uu Sukaesih, from the collection of professional zakat, Banjar City was able to raise Rp. 9 billion per year (radartasikmalaya.com, 2018). If the fund can be managed properly for the benefit of the people it will have a good impact so that the living standards of the people in Banjar City can increase.

Zakat in its implementation has three main dimensions, namely the personal spiritual dimension, social dimension and economic dimension. In Islam, zakat is an obligation that must be carried out by a Muslim as a means of purifying property and soul. So that by paying zakat, it will encourage someone to have a high work ethic. Then the main concept of zakat is as a tool to promote equitable economic growth and sharing mechanisms in the economy. If implemented and managed properly, these three dimensions can have a positive impact on human development which consists of health, education, and decent living standards (Nurzaman, 2011).

Some studies reveal that the results of community empowerment using zakat funds have a positive impact but are less significant on improving the standard of living of the community. As in the study by Achmad Syaiful Hidayat Anwar who conducted research on the impact of zakat on the mustahik economy in the area of operation and distribution of Amil Zakat Agencies and Institutions (BAZ and LAZ) in Malang. From this study, it was found that the amount of mustahik that had increased living standard after being given zakat was only $0.1 \%$ to $25 \%$.

According to the observations from Achmad Syaiful Hidayat Anwar this condition was caused by the economic conditions of Mustahik that had not been detected as a whole, lack of implementing human resources, and the limitations of the database related to mustahik or indirectly indicate the lack of precise program objectives and the inappropriate treatment (empowerment) carried out by LAZ and BAZ institutions (Anwar, 2016).

In overcoming these problems, BAZNAS issued an indicator called the Zakat Village Index (IDZ) so that the zakat funds distributed by BAZ and LAZ institutions could be 
channeled optimally, on target and in accordance with the needs of mustahik in an area, especially the village as a scope the small one in a country.

The Zakat Village Index or abbreviated as IDZ is a mechanism used to measure the condition of a village to be said to be feasible or not feasible assisted by zakat funds. The next stage the amilins in BAZ and LAZ can always monitor and evaluate the zakat programs carried out in a village. This is done so that the zakat program implemented will be right on target and have a more effective impact in improving the living standards of the mustahik in an area, especially the village.

Thus, the authors are interested in conducting research that discusses the size of the feasibility of a village to be empowered from zakat funds. This study will measure how worthy of Binangun Village, Pataruman Subdistrict, Banjar City to be used as a zakat village measured using the Zakat Village Index. Therefore, this study is entitled "Implementation of Zakat Village Index (Survey in Binangun Village, Pataruman District of Banjar City) through the formulation of the problem: (1) How high is the value of the Zakat Village Index (IDZ) in Binangun Village, Pataruman District Banjar City? Is Binangun Village, Pataruman District Banjar City worthy of being empowered as a zakat village based on the Zakat Village Index (IDZ)?

Based on the explanation of the above problems, the purpose of this research is to build a conceptual model that can describe and measure the condition of a village to be said to be empowered as a zakat village using the Zakat Village Index (IDZ).

\section{Literatur Review}

\subsection{The concept of Zakat}

Zakat is one part of the pillars of Islam and the only pillar of Islam that specifically mentions and spears the economy of Muslims. Zakat is currently one of the financial instruments that are expected to be able to overcome various kinds of crucial economic problems in society such as poverty, inequality and unemployment (Muhamat, 2013).

According to Prayitno in etymologically zakat is derived from the basic verb (fi'il madhi) zaka, which means, to grow and develop (zaka al-zar ': the plant has bloomed), to give blessings (zakat al-nafaqal: the provision of give blessings, increase goodness (fulan zaak: one who increases his goodness), sanctify (qad aflaha man zakkahu: lucky person who is able to cleanse his soul), and flatter (fala tazku anfusakum: never praise yourself) (Hapsari, 2016). 
Zakat according to the terminology means a certain amount of assets required by Allah Subhanahu wata'ala. It is given to mustahik (people who have the right to receive zakat) who are mentioned in the Qur 'an. It also means a certain number of a particular asset which is given to a specific person. Zakat can also mean a number of assets which are taken from people who give zakat (Pahala, 2013). In the other words Zakat is an activity to give certain assets which are obliged by Allah SWT in certain amounts and calculations to be submitted to those who are entitled (Djaghballou, 2017).

Basically, in the Islamic government system, zakat is an instrument to avoid man from Kanzu adh-dzahab wa alfidhah's behavior, which is the activity of hoarding and accumulating wealth in the form of money and gold in amounts exceeding his Nisab. The hoarding is intended not to finance the needs planned or used as business capital, but only to be stored both inside and above the ground (Juliana, 2017).

In the implementation mechanism, zakat involves all levels of society, whether the community is classified as having more assets (muzakki) and the community is classified as less material (mustahik). By involving zakat as an instrument of development, each group of people will be able to fulfill their basic needs. Zakat also allows people who are classified as poor to take part in taking part in the socio-economic sphere (Suhaib, 2009).

\subsection{Productive Zakat}

According to Kiai Shahal productive zakat is the provision of zakat which makes the person who receives (mustahik) able to produce something consistently with the zakat that he receives (Ma'mur, 2015).

Whereas according to Asnaini Productive zakat is distributing zakat funds to the every mustahik in a productive way. Zakat is given as business capital, which will develops their business to meet the needs of life throughout their life (Mayes, 2017).

\subsection{Indeks Desa Zakat}

Zakat Village Index or abbreviated with IDZ is an indicator that is able to measure (condition) conditions and conditions of a village whether the village is feasible or not to be empowered by using zakat funds. Village Index Zakat is also compiled based on process-oriented where IDZ itself will later measure and assess various kinds of village development efforts. Therefore IDZ itself can be used as a mechanism to measure the welfare of a village and can also be used as a monitoring and evaluation tool for 
the zakat village program that has been carried out by zakat management institutions. So that with the existence of IDZ it is expected to be able to help zakat management institutions that will or are running an empowerment program with zakat funds especially for those who implement the zakat village program.

Because IDZ serves to be a measuring tool for empowering zakat institutions, the operationalization of IDZ itself is more focused on zakat fund distribution programs that are productive (Tim Riset dan Kajian PUSKAS BAZNAS, 2017).

\section{Methodology}

In this study researchers used quantitative descriptive research methods. This research was conducted in Binangun Village, Pataruman District Banjar City which was recommended by BAZNAS Banjar City to be empowered to use zakat funds.

The population of this study were all residents of Binangun Village, Pataruman District, Banjar City, totaling 5,103. Because of the limitations of the researcher, the assessment of several indicators does not involve the entire population but the assessment is considered and validated by experts and local community leaders or what is called (expert judgment). According to Mardapi, this expert judgment method can be used as an alternative validation but with experts who are in accordance with their respective fields (Astuti, 2015).

In this study, to obtain relevant information in order to support research, the authors used data collection methods by means of library research, field research in the form of interviews, questionnaires and documentation studies.

The data analysis tool used in this study uses the calculation of the Zakat Village Index which is part of a quantitative method that has its own formula also through several stages of calculation. The following stages of the calculation process of the Zakat Village Index:

$$
I i=\frac{(\mathrm{Si}-\mathrm{Smin})}{\mathrm{Smax}-\mathrm{Smin}}
$$

Description:

$l i=$ index on variables $i$

$\mathrm{Si}=$ Actual score value on variable measurement $\mathrm{i}$

Smax $=$ Maximum Score (5)

Smin $=$ Minimum Score (1)

After the value of each indicator is obtained, then multiplied by the weight of each indicator to get an indicator index. 
Then the indicator index is grouped according to its dimensions, and multiplied by the weight of each dimension to get the dimension index.

The index of each variable is multiplied by the weight of each variable to get a variable index. The result is a composite index which can be referred to as the Zakat Village Index. The formula is as follows:

$$
I D Z=(X 1 e k+X 2 k s+X 3 p e+X 4 k e+X 5 d a)
$$

Description:

IDZ = Zakat Village Index

$\mathrm{X} 1, \ldots, \mathrm{X} 5=$ Assesement value

ek $=$ Economic variables

ks $=$ Health variable

pe $=$ Education Variables

ke $=$ humanitarian variable

da $=$ Da'wah Variables

The Zakat Village Index value ranges between 0 and 1. The closer to 1 the village is not prioritized for assistance. Conversely, the more IDZ approaches 0, the village will be prioritized for assistance. The weight of the assessment itself as can be seen on the table

TABLE 1: Score Range Zakat Village Index.

\begin{tabular}{ll|l} 
Score Range & Explanation & Interpretation \\
$0,00-0,20$ & Not Good & Highly prioritized for assistance \\
$0,21-0,40$ & Not Good Enough & Prioritized for assistance \\
$0,41-0,60$ & Petty Good & Can be considered for help \\
$0,61-0,80$ & Good & Less prioritized for assistance \\
$0,81-1,00$ & Great & Not prioritized for assistance \\
\hline Source: Central BAZNAS strategic study (PUSKAS BAZNAS) &
\end{tabular}

\section{Result}

Several studies have proven that in general zakat can improve welfare and become an effective mechanism to reduce poverty in a country. Zakat also greatly influences the distribution system of wealth by increasing the economy of the community and focusing on household consumption by fulfilling the basic needs of the community (Abdullah N., 2015). 
This section will discuss the results of IDZ values based on data that has been processed by the researcher. The discussion of the results of the IDZ Impelementation research will be divided based on the value of each variable and the overall IDZ Village Binangun value discussion.

\subsection{IDZ characteristics based on economic variables}

Based on IDZ calculation results, the economic variable value of Binangun Village gets a value of 0.37 which means that the economic condition of Binangun Village is at an unfavorable level so it is prioritized for assistance. This value is influenced by the absence of several variables that support the economic variables in Binangun Village. Like there is no market as a means of trade and provider of community needs both offline and online, then there is no minimarket or shopping complex, moreover the absence of financial institutions both sharia and conventional.

The value of each dimension in Binangun Village's economic variables is influenced by several indicators. Productive economic activities that have an IDZ value of 0.42 , which means that the productive economic activities of Binangun Village are included in a fairly good condition. This is influenced by several indicators, among others because Binangun Village itself has three superior products namely woven sticks, fruits and bamboo creations. Then as many as $53 \%$ of the population in productive age (15-64 years) have a livelihood. Meanwhile, Binangun Village also has a creative industry activist community, namely saung gawir which produces bamboo creations.

The dimensions of the village trade center have an IDZ value of 0.12 , which means that trading activities in Binangun Village are in a bad condition. This is because in Binangun Village itself there is no market as a village trade center, then there are no other trading places such as shopping complexes or minimarkets available in the village.

Dimensions Access to transportation and logistics delivery services in Binangun Village has an IDZ value of 0.74 , which means that access to transportation and shipping logistics services in Binangun Village are in good condition. This is influenced by the accessibility of village roads that are easy because of land transportation, and can be passed by four-wheeled vehicles. Then in the village of binangun there are also public transports with routes that remain and operate every day. But unfortunately, in Binangun Village there is no logistical service or freight forwarding services such as JNE, J \& T or post office.

The last dimension in the economic variable is the access of financial institutions in Binangun Village to get an IDZ value of 0.255 which means that access to financial 
institutions of the binangun community is in poor condition. This is influenced by the unavailability of financial institutions in Binangun Village, both the convinial and sharia. Then as many as $23 \%$ of the villagers of Binangun are still involved in transactions with moneylenders. However, around $70 \%$ of the people also have used financial services either just to save or make loan transactions.

\subsection{IDZ characteristics based on health variables}

Based on IDZ calculation results, the health variable value of Binangun Village got a value of 0.43 which means that the health condition of Binangun Village is at a level that is good enough so that it can be considered for assistance.

The health variable value of Binangun Village above is influenced by the absence of several dimensions that support health in Binangun Village. The value of each dimension is also influenced by several indicators. The public health dimension in Binangun Village has an IDZ value of 0.815 , which means that the community health condition of Binangun Village is in the very good category. This is because about $50 \%$ of people's homes use clean water for cooking and MCK (bathing latrines). Then more than $80 \%$ of residents' homes also have bathrooms and latrines inside the house and have access to protected drinking water such as tap water and wells.

The second dimension is that the dimensions of health services in Binangun Village get an IDZ value of 0.125 which is categorized as not good. This is influenced by the unavailability of puskesmas and polindes inside. Then only seven RWs in Binangun Village had posyandu out of a total of 14 RW. There are no certified doctors or nurses in the village of Binangun, so the community has difficulty accessing health facilities.

The last dimension of the health variable, namely health insurance, has an IDZ value of 0.25 , which means that health insurance in the village of Binangun belongs to an unfavorable condition. This is because the population of BPJS participants in Binangun Village is only around 23\% (registered in the Village).

\subsection{IDZ characteristics based on education variables}

The level of intellectual development of human resources is key to post-industrial economic indicators. Thus, high competitiveness in the scope of education becomes an indicator of economic development as well as an indicator of the level of individual quality in a country (LEVCHENKO, 2017). 
Based on IDZ calculation results, the value of the Binangun Village Education variable gets a value of 0.6 , which indicates that the education conditions of Binangun Village are at a fairly good level so that education in Binangun Village can be considered for assistance.

The value of the education variable in Binangun Village is influenced by two dimensions. The first dimension is the level of education and public literacy which has an IDZ value of 0.52 which means that the level of education in Binangun Village is in a pretty good condition. This is because it is influenced by the conditions of several indicators including the number of Binangun villagers who have received formal education for more than 12 years (up to tertiary education) of less than $20 \%$, but all residents who are aged 15 to 45 years can read and count.

The second dimension is education facilities in Binangun Village which have a value of 0.657 and are included in the good category. This is because classrooms are available for each study group which is equipped with all classroom equipment such as tables, chairs and blackboards. Then the community access to school both elementary, junior high and high school is easy and the closest distance is around four to six kilometers. Then every teacher in the school at least provides 21 to 25 children per class.

\subsection{IDZ characteristics based on social and humanitarian variables}

Based on the IDZ calculation results, the value of the Social and Humanity variables in Binangun Village got a value of 0.75 which shows that the social and humanitarian conditions of Binangun Village are at a good level so that the social and humanitarian aspects of Binangun Village are not prioritized to be helped.

The value of the social and humanitarian variables Binanung village is influenced by several dimensions. The first dimension is the public interaction space facility which has an IDZ value of 0.89 , which means that this dimension belongs to the very good category. This is influenced by several factors, including in Binangun Village there are 13 fields for exercise, namely one soccer field, seven volleyball courts, 2 badminton courts and two tennis courts. then in Binangun Village there were also five community and community activity groups such as farmer groups, fellowship bodies, youth groups, saung gawir groups and PKK women's groups.

The second dimension is electricity, communication and information infrastructure which has an IDZ value of 0.8175 and is included in a very good condition. This is because it is influenced by several things including the percentage of families of 
electricity users in Binangun Village reaching 100\%. Then in Binangun Village there was a cellular telecommunications signal but the signal was still weak (one to two bars). Secondly, around $25 \%$ of the people of Binangun Village have accessed the internet as a source of information and communication and more than $80 \%$ of the communities in Binangun Village can access television or radio.

The last dimension is the natural disaster itigation in Binangun Village which has an IDZ value of 0.5 and is included in a fairly good condition. This is influenced by several indicators, including Binangun Village, which has two natural disaster management planning criteria and an early warning system for natural disasters.

\subsection{Characteristics of IDS based on variable Da'wah}

Based on the results of IDZ calculations, the value of the Binangun Village Da'wah variable gets a value of 0.54 which indicates that the da'wah activities are at a fairly good level so that aspects of Binangun Village's religious activities can be considered for assistance

The value of the da'wah variable in Binangun Village is influenced by several dimensions including the dimensions of facilities and religious companions who have an IDZ value of 0.8425 which means that this dimension is included in a very good condition. This is because in Binangun Village itself there is at least one mosque which is easily accessible and accessible to more than $81 \%$ of the villagers. Then the closest distance taken by the residents to the nearest mosque is around one meter. Then in the village of binangun there were 36 religious assistants scattered throughout the RW.

The second dimension is the level of religious knowledge of the community which has the highest IDZ value, which means that the level of religious knowledge of the binangun village is very good. This is influenced by several indicators including more than $80 \%$ of the Muslim community in Binangun Village can read the Qur'an. The loss of all Muslim communities in the village of Binangun which is included in the muzakki to pay zakat fitrah

The last dimension is the level of religious activity and community participation having an IDZ value of 0.305 which indicates that this dimension is in an unfavorable condition. This is influenced by several factors including village religious routine activities held once a month. But unfortunately the number of people who attend prayers are obliged to congregate every day only about $20 \%$ of the number of Friday prayers. Then around $50 \%$ of the villagers participated in every religious activity held by the village. 


\subsection{IDZ value of Binangun village, Pataruman district, Banjar city}

Following the results of the implementation of the Zakat Village Index (IDZ) in Binangun Village, Banjar City to measure how worthy the Binangun Village is empowered to use zakat funds.

TABLE 2: IDZ Value Of Binangun.

\begin{tabular}{l|c|l}
\hline Variabel & Nilai IDZ & Keterangan \\
\hline Ekonomic & 0,37 & Not Good \\
\hline Health & 0,43 & Petty Good \\
\hline Education & 0,60 & Petty Good \\
\hline Social and Humanity & 0,77 & Good \\
\hline Da'wah & 0,69 & Good \\
\hline Total IDZ keseluruhan & $\mathbf{0 , 5 6}$ & Cukup Baik \\
\hline Source: Processed by the researcher &
\end{tabular}

Based on the data in Table 2, we can see that Binangun Village has a Village Zakat Index of 0.56. This means that Binangun Village belongs to the village category that is good enough and can be considered to be empowered using zakat funds.

\section{Conclusion}

Based on the problem formulation and analysis of research results, the conclusion in this study is that Binangun Village Pataruman District Banjar City has a Zakat Village Index (IDZ) of 0.56, which means that the village is included in the village condition which is good enough but can be considered empowered using zakat funds. The economic variable value of the Binangun Village based on the results of the Zakat Village Index (IDZ) is included in the unfavorable category and prioritized for assistance. While the health variables in Binangun Village are in a good enough category but have a low value so that the health aspects of the community in Binangun Village can be considered for assistance. In addition, the education variables themselves are in a pretty good category but can be considered for assistance. The social and community variables of Binangun Village get the highest IDZ value among other variables and are in good condition so that they are less prioritized to be helped. The last is the da'wah variable in the village is in good condition so that it is not prioritized to be helped

From the results of research and calculation of IDZ values, according to researchers, the Binangun Village is still a good category to be empowered with zakat funds. But 
indeed only a few aspects that are the focus of zakat institutions to empower Binangun Village include economic and health aspects that have the lowest IDZ value among other variables

[1] Abdullah, N. (2015). The Effectiveness of Zakat in Alleviating Poverty and Inequalities. Humanomics, 324.

[2] Anwar, A. S. (2016). Model Pemberdayaan Ekonomi Mustahiq Melalui Zakat. JEAM Vol XV, 54.

[3] Hapsari, M. I. (2016). Zakat Distribution in Maqasid Al-Shariah Framework: Journal of Islamic Financial Studies, 17.

[4] Dijawabarat.com. (2018). Gawat, Inilah 5 Kota Termiskin Di Jawa Barat Versi Pemerintah Jabar 2017. Bandung: http://dijawabarat.com.

[5] Djaghballou, C. E. (2017). E?ciency and productivity performanceofzakat funds in Algeria. International Journal of Islamic and Middle Eastern Finance and Management, 2.

[6] Hartoyo, S. (2010). Pengentasan Kemiskinan Berbasis Zakat: Studi Kasus di Garu. lqtishodia, 6.

[7] Juliana. (2017). Uang dalam Pandangan Islam. Amwaluna, Vol. 1 No.2 . 228.

[8] LEVCHENKO, O. M. (2017). The Impact of Higher Education on National Economic and Social Development:. Journal of Applied Economic Sciences, 8.

[9] Ma'mur, J. (2015). Zakat Produktif: Studi Pemikiran K.H. Ma. Sahal Mahfudh. Religia Vol. 18 No. 1, April 2015, 120.

[10] Mayes, A. (2017). The Role of Productive Zakat for Helping Poor munity in Rokan Hulu Regency (Case Study of National Amil Zakat of Rokan Hulu Regency). International Journal of Finance and Accounting, 181.

[11] Muhamat, A. A. (2013). An appraisal on the business success of entrepreneurial asnaf. Journal of Financial Reporting and Accounting, 54.

[12] Nurzaman, M. S. (2011). Zakat and Human Development: An Empirical Analysis on Poverty Alleviation in Jakarta, Indonesia. 8th International Conference on Is/amic Economics and Finance, 1.

[13] Pahala, I. (2013). Zakat is More Significant Than Tax. Review of Integrative Business and Economics, 290.

[14] Rachman, F. F. (2017). Orang Miskin Terbanyak di Jawa, Persentase Terbesar di Maluku-Papua. Jakarta: https://finance.detik.com. 
[15] Radartasikmalaya.com. (2018). ASN Banjar Sudah Keluarkan Zakat Sejak 6 Tahun Lalu. Banjar: https://radartasikmalaya.com.

[16] Suhaib, A. Q. (2009). Contribution of Zakat in the Social Development of Pakistan. Pakistan Journal of Social Sciences (PJSS) , 313.

[17] Tim Riset dan Kajian PUSKAS BAZNAS. (2017). Indeks Desa Zakat. Jakarta: PUSKAS BAZNAS. 